The Nature of Work 
Also by Paul Thompson (with Eddie Bannon)

Working the System: Workplace Organisation and the Labour Process in Telecommunications 


\section{The Nature of Work}

An introduction to debates on the labour process

Paul Thompson

M 
() Paul Thompson 1983

Softcover reprint of the hardcover 1st edition 1983

All rights reserved. No part of this publication may be reproduced or transmitted, in any form or by any means, without permission.

First published 1983 by

THE MACMILLAN PRESS LTD

London and Basingstoke

Companies and representatives throughout the world

ISBN 978-0-333-33027-2

ISBN 978-1-349-17194-1 (eBook)

DOI 10.1007/978-1-349-17194-1

Typeset in Great Britain by

STYLESET LIMITED

Salisbury, Wiltshire 
To Betty and John

Elsie and Reg 


\section{Contents}

Preface $\quad$ xi

Glossary of Labour Process Terms xiii

Introduction $\quad 1$

PART ONE THE ESTABLISHED TRADITIONS

1 The Sociological Study of Work 11

Workplace Behaviour 13

Origins of industrial sociology $\quad 14$

Post-war plant sociology $\quad 15$

$\begin{array}{ll}\text { Technology, work organisation and alienation: a } & 19\end{array}$

Organisation, Hierarchy and Control 23

Bureaucracy and capitalism $\quad 25$

Radical perspectives $\quad 28$

Class, Work and Industrial Society $\quad 29$

Orientations to work $\quad 30$

Post-industrial societies $\quad 32$

Conclusion: Contrasts and Continuities $\quad 34$

2 Marx and the Idea of the Labour Process 38

The General Character of the Labour Process 38

The Capitalist Labour Process $\quad 40$

From the workshop to large-scale industry 43

The division of labour $\quad 44$

Mechanisation and its effects $\quad 46$ 
Theory and Reality: a Reflection

One Step Backwards: Explaining the Drift from the Labour Process

Politics and the workplace

Already existing socialism

\section{PART TWO THE CONTEMPORARY DEBATES}

3 Braverman and the Re-discovery of the Labour Process

New Beginnings: Theory and Practice

The Degradation of Work: the Braverman Thesis

Taylorism and control

Deskilling: science and technology in the service of capital

From production to society

The class structure

Conclusion

4 Deskilling: The Degradation of Labour?

The Deskilling Debate

Craft: Destruction and Resistance

The perspective

The critique

The Theoretical Issues

Labour markets and capitalist development

The application of new technology

5 Forms of Control and Resistance 
The Frontier of Control

Direct control and responsible autonomy 134

The significance of job enrichment 138

A new frontier? 143

Contested Terrain: the Edwards Thesis 144

Managerial experiments 144

Interrelations between modern control structures 146

Conclusion: the Dimension of Control 150

6 Legitimation and Consent in Work 153

Work and Consciousness: Alternative Problematics 155

Traditional Marxism $\quad 155$

Sociology 157

The Manufacture of Consent 159

Games and practices $\quad 160$

From coercion to consent? 163

The Limits to Workplace Consent $\quad 165$

The perpetuation of conflict 167

The Relevance of External Factors $\quad 170$

Class, culture and trade unionism 172

The social preparation for work $\quad 175$

Conclusion: Integrating Consent 176

7 The Other Division of Labour $\quad 180$

Women: Labour Market and Labour Process 181

Opportunity and inequality 182

The academically invisible woman? 184

The Application of Marxist Categories $\quad 187$

Marx and female wage labour 188

Braverman: the feminist critique $\quad 190$

An industrial reserve army? 192

Conclusion 195

Patriarchy and Capital 196

The parameters of partnership $\quad 198$

The Family, Wages and Work 201

The feminisation of jobs 203

The consolidation of women's work 205

Recent trends 206

Conclusion: the Analysis of Stratification 207 
PART THREE THE THEORETICAL AND PRACTICAL CONSEQUENCES

8 The Theory and Politics of Production 213 Summary 214

The Distinctiveness of the Capitalist Labour Process 216 The labour process in Eastern Europe 217 Theoretical consequences 224 Remaking Class Society 227

The labour process and class analysis $\quad 227$

Work and social change $\quad 230$

Concepts reconsidered 234

Resistance and Transformation $\quad 236$

Types of politics 236

Workplace practices and strategies $\quad 239$

$\begin{array}{ll}\text { End-notes } & 246\end{array}$

Guide to Labour Process Literature $\quad 271$

$\begin{array}{ll}\text { Bibliography } & 276\end{array}$

Index 294 


\section{Preface}

My interest in the labour process first developed in political activity with shop stewards and shopfloor workers in the motor industry on Merseyside in the early 1970s. The experiences of the restructuring of work and pay began to be put to academic use in subsequent years of part-time research at Liverpool University. At first most of the innovative writings on the changing nature of work and class derived from Italy and France. All that changed with the publication of Braverman's Labor and Monopoly Capital in 1974, and the explosion of interest in the labour process that followed in its wake.

My research became increasingly directed towards tying together and evaluating the new debates, comparing them with older sociological traditions. This book draws on the knowledge I gained in those years, although its scope, aims and content are very different. I owe a considerable debt to Tony Lane for his encouragement and support through that period. Richard Hyman, too, was kind enough to give me some very useful advice which helped me to revise a number of my ideas about labour process theory and its limitations.

In working on the present book, my thanks go to Theo Nichols for a set of fair and useful comments on the whole manuscript, and to Dave Robertson and Lynne Segal for looking at particular chapters. I have continually drawn on the advice and knowledge of Mike Jones, the discussions between us contributing considerably to the development of my own ideas. In addition, the critical attention of Hazel Davies to the style of the manuscript has greatly added to its 
readability. My editor at Macmillan, Steven Kennedy, has also been an invaluable source of help in improving its form and content. Responsibility in all respects remains, of course, my own.

Thanks also go to Jean Pearson for work on the bibliography and index; and while most of the typing of the manuscript was my own, Tricia Houghton was kind enough to help with some of the chapters. Most of all, I would like to record my debt to Jill and our daughter Jane who have tolerated what often appeared to be endless periods of work on the book and its forerunners. Without their support such efforts could never have been completed.

Liverpool

December 1982 


\section{Glossary of Labour Process Terms}

The aim of this glossary is not to produce a set of definitions for the complete range of sociological and Marxist concepts, but rather to deal with those terms used throughout the text which have specific relevance to the labour process.

alienated work Work performed under conditions in which the worker is estranged from his or her own activity in the act of production, through the sale of labour power and the subordination of skills and knowledge to the capitalist, or other external social forces.

automation A form of production in which all manual intervention by the worker is eliminated, in some cases to be replaced by supervision, monitoring or control of machinery. It includes a number of types such as continuous process, numerical control and automated assembly; and is distinguished from mechanisation, which concerns the operation of tools or machinery through sources independent of the worker's manual dexterity.

capitalism A mode of production based on the generalised production of commodities for exchange and profit.

collective worker At a certain stage of capitalist production, manual and intellectual workers are combined together in association by the machine system. The term is used to stress the partial interchangeability of functions, and the potential for genuine co-operation in the labour process in a socialist society. See also homogenisation. 
control system Mechanisms by which employers direct work tasks, discipline and reward workers, and supervise and evaluate their performance in production. See also subordination.

deskilling Incorporation of the crafts, knowledgable practices and elements of job control held by workers into the functions of management, or operation of machinery.

division of labour This is not the existence of different jobs, but the simplifying and fragmentation of tasks into smaller parts, so as to cheapen and control the costs of labour. Marx also uses a distinction between this technical division and the social division of labour, related to wider societal processes through which workers are allocated to different branches of production. This has relevance to the analysis of relations between social hierarchies of race and sex, and hierarchies in work.

fetishism The process in production whereby the workings of the market, exploitation and private ownership appear as natural and inevitable rather than social relations capable of transformation.

forces and relations of production A distinction between skills, machinery and other physical properties of production, and the social relations of ownership, command and control. These are held by Marx to act constantly on one another, enabling a critique to be made of those who believe that science and technology are neutral.

Fordism A term used by some labour process theorists which extends the technique of factory production - based on the assembly-line - developed by Ford into a category referring to a general stage in capitalist production.

homogenisation Controversial term used by Marx and other labour process writers to refer to the equalisation of types of work under the impact of deskilling and related trends.

intellectual and manual labour All human labour involves mind and body, but this concept is used to describe the separation of conception and execution that is built into the design of jobs, reflecting the objectives of capital.

job enrichment One form of work humanisation by employers. It is often used as a generic description of a number of different processes of enlarging, aggregating and rotating tasks. 
labour market The means of allocating and pricing jobs in the economy as a whole, and within particular firms (an internal labour market).

labour power The capacity to work which is transformed into labour that produces value for the capitalist through the creation of commodities.

labour process The means by which raw materials are transformed by human labour, acting on the objects with tools and machinery: first into products for use and, under capitalism, into commodities to be exchanged on the market.

large-scale industry A term used by Marx to distinguish between the mature factory system in which the labour process is transformed by the uses of science and machinery, and previous stages such as manufacture (dominated by the introduction of the division of labour), and cooperation (characterised by the concentration of workers into the same or connected processes by the capitalist).

reproduction of labour power The wider means of ensuring the continuity of wage labour through the organisation of the fundamental material and social needs of human life food, clothing, leisure, etc. This is a crucial part of connections between the labour process and institutions such as the family.

reserve army of labour What Marx described as a relative surplus population of unemployed workers, or potential workers - such as the sporadically employed, housewives and migrants - who form a necessary part of the working mechanisms of the capitalist mode of production.

subordination of labour Marx used these terms in a more precise way than that of control. The formal subordination of labour is established when workers and their skills are subsumed in a labour process under the control of the capitalist. This is ultimately transformed into real subordination through the incorporation of science and machinery within the expanded scale of production - which, in turn, allows a qualitatively new and more effective means of domination of labour.

Taylorism Management control strategy named after F. W. Taylor. The first systematic theory and practice of management, its defining characteristic has been the attempt to 
xvi

Glossary of Labour Process Terms

separate mental and manual labour, subjecting both to exact measurement. Taylorism spawned a more general movement known as scientific management.

valorisation The process of creating surplus value. The labour process only becomes distinctively capitalist when it is combined with valorisation.

worker resistance A widely used term by labour process writers to refer to informal and organised worker opposition to management and employers in the labour process. It is more specific to work than the often misleading application of the concept of 'class struggle'. 